\title{
The Genesis of the Roma Emancipation
}

\author{
1.1 The Austro-Hungarian Empire
}

\subsubsection{The Gypsy Voivodina}

1.1.1.1 János Kaldarás and Mihaly Szava

Kaldarás János, ki magát Biharban, Szunyogd környékén ideiglenes cigany vajdának, társával, Szava Mihaly szunyogdi lakossal együtt egy folyamodványt nyújtottak a magyar kir. udv. kancelláriához, melyben egy cigány-vajdasag fölállitásaért esedeznek. Csak a cigányok voltak még hátra, hogy ök is külön autonomiát sürgessenek.

Janos Kaldaras, located in Bihar [1], in the vicinity of Szunyogd [2], a temporary Gypsy Voivode, and his companion Sava Mihaly from Szunyogd, have applied to the [Hungarian] Royal Office for a Gypsy Voivodina [3] to be established [4]. There now remained only Gypsies who would call for their own autonomy [5].

\footnotetext{
Notes

1. Today, Bihor County in Romania.

2. Today, Suiug in Romania.

3. In Hungarian original, the term 'Vajdasag' has been used. It refers to term 'Vajda', which is the hungarianised form of the term 'Voivode'. Today, the designation 'vajda' has become popular in the Romani language in Central Europe and it refers to the leader/representative of a certain Roma community.

4. 'Vajdasag' (Voivodina) here is used in the sense of a separate territorial-administrative unit. 'Voivode' (Voievod, Vojvoda, Wojewoda) is a Slavic term for a military commander in Central, Eastern and South-Eastern Europe during the Middle Ages, or a governor of a territorial unit.

5. It means to say that all nationalities have already asked for their autonomies while the Gypsies have been the last.
}

Source: [No Author]. (1865). [No Title]. Fóvárosi Lapok, 1865, July 19, p. 622.

Prepared for publication by Elena Marushiakova and Vesselin Popov.

1.1.1.2 The two Gypsy Chieftains

Zwei Zigeunerhäuptlinge aus dem Bihàrer Komitate haben in neuster Zeit ein Besuch bei der ungarishen Hofkanzlei eingereicht, worin sie für sich und ihre Stammesgenossen um Errichtung einer geografisch abgegrenzten "Zigeuner-Wojwodina" in Ungarn bitten. Das wäre eine nagelneue politisch - historische Individualität.

Two Gypsy chieftains from the Bihor County [1] have recently paid a visit to the Hungarian Royal Office asking for the establishment for themselves and their tribesmen of a 
geographically separate "Gypsy-Voivodina" in Hungary. That would be a brand new political-historical unit.

\section{Notes}

1. The original uses the term 'Komitat' was to refer to the territorial-administrative units at that time.

Source: [No Author]. (1865). [No Title]. Klagenfurter Zeitung, 1865, August 8, p. 719.

Prepared for publication by Elena Marushiakova and Vesselin Popov.

\section{Comments}

The presented materials reveal the aspirations of Janos Kaldaras and Sava Mihaly to gain public and political recognition of the Gypsy community by establishing a separate territorial-administrative unit (Voivodina) within the Habsburg Empire. The emergence of such aspirations could be understood given the general socio-political context. After the Revolutions of 1848, which marked the beginning of modern nationalism in Europe, for two decades the then Habsburg Empire was constantly shaken by the attempts of individual nationalities to gain some form of political autonomy. These processes reached their pinnacle in 1867 when the Empire was forced to "ethnicise" and transform itself into a dual Austro-Hungarian Empire while their continued development, and because of the context of World War I, led to its collapse in 1918. This influence of the general social context has been even noted by the unknown author of the publication in newspaper Fövárosi Lapok, who explicitly noted that the Gypsies were the last nationality in the Empire that expressed their wish for autonomy. There is a certain irony in this note (in the sense that even (sic!) Gypsies have already sought autonomy), which allows us to guess what the result of their representatives' public address to the authorities was, although no historical evidence for this could yet be found. It can be argued with great confidence that the authorities did not pay any attention to them, which is understandable given the general public disdain of the Gypsies.

The very idea of political representation of the Gypsy community does not appear in a completely random place. During the Hungarian Revolution of 1848 , Nikola Mihailo (born 1810), a nomad Gypsy from Banat, joined of the Revolutionary Army and was recognised by the provisional Hungarian authorities as the 'Voivode of the Gypsies', while the Gypsies from Banat themselves declared him to be their 'King' and called him Nikola Mihailo Mali. After the defeat of the Hungarian Revolution, he emigrated to Smederevo (Serbia) and from there to Cleveland (USA) where he again declared himself as 'King of the Gypsies' and where he died in 1910 (Pavlović, 1969; Acković, 2012, pp. 144-145).

There is another important conclusion that could be made by looking at the published materials. As it has been explicitly noted in Fóvárosi Lapok, Janos Kaldaras is located around Szunyogd, while Sava Mihaly is from Szunyogd. In other words, the former lead a nomadic way of life while the latter lived a sedentary one. That is probably the first historical evidence of an active collaboration between Roma leading different ways of life in the name of a common idea for the whole community. Keeping in mind the internal heterogeneity of the Roma community and the complex relationships (in many cases not 
accepting, rejecting and even sharp oppositions) between the Roma groups, as its main constituent units (Marušiakova, 1988; Marushiakova \& Popov, 1997b; 2016a), this unique case (for the time being), may be explained by the desire of the community to reach another dimension and become an integral (and, most of all, equal) part of the society. For this aim to be achieved, a necessary condition was needed: first and foremost, that the community be united and overcome its internal oppositions due to its heterogeneity (a process that cannot be regarded as complete to this day). In fact, that is the true beginning of the Roma civic emancipation.

Elena Marushiakova and Vesselin Popov

\subsubsection{The Gypsy Congress in Kisfalu \\ 1.1.2.1 The Gypsy Congress}

Ein Zigeunerkongress

Eine sonderbare Synode fand, wie die "Kaschauer Ztg." berichtet, in Kis-falu statt. Sie wurde nämlich von den oberungarischen Zigeunern abgehalten, welche an diesem Tage von Nah und Fern zur Besprechung “der gemeinsamen Interessen” zusammenströmten. Bei solchen Gelegenheiten finden, wie das erwähnte Blatt weiter berichtet, in der Regel zahlreiche Eheschließungen in Zigeunervolke statt.

\section{A Gypsy Congress}

A strange Synod took place in Kisfalu [1], as the Kaschauer Ztg. reported, it was held by the Upper Hungarian Gypsies, who converged on this day coming from close by and from far away to sweep up "the common interests". On such occasions, as the aforementioned newspaper further reported, usually many marriages take part among the Gypsies.

\footnotetext{
Notes

1. The name itself, 'Kisfalu', in Hungarian means a small village. This is most probably the village Malá vieska (a 'small village' in Slovak) located $8 \mathrm{~km}$ north from the city of Košice in Slovakia. Today it is a part of village Družstevná pri Hornáde.
}

Source: [No Author]. (1879). [No Title]. Epoche, 1879, September 13, p. 3. Prepared for publication by Elena Marushiakova and Vesselin Popov.

1.1.2.2 The Gypsy Day

\section{Der Zigeunertag}

Bei der in Kis-Falu behufs Besprechung gemeinsamer Interessen stattfindenden Versammlung oberungarischer Zigeuner dürften folgende als die ersten und wichtigsten Punkte verhandelt werden:

1. Förderung der frühzeitigen Unterrichtes der Kinder beiderlei Geschlechtes im Betteln. 2. Gründliche Unterweisung der Weiber im Wahrsagen aus den Händen. 
3. Erledigung der Frage: Wie kann man am Sichersten was mitgehen lassen, ohne erwischt zu werden? 4. Erwirkung des activen und passiven Wahlrechtes für den ungarischen Reichstag, behufs Einflußnahme bei Ausarbeitung eines mit möglichster Berücksichtigung unbeirrten Freizügigkeitsrechtes zu erlassenden neuen Vagabundengesetzes.

\section{The Gypsy Day}

At the gathering of Gypsies in Kisfalu for the purpose of discussing common interests, the following should be negotiated as the first and most important ones:

1. Promote the early education of children of both sexes in begging. 2. Thorough training of women in fortune-telling from the hands. 3. Completing the question: how can one most safely let something go without being caught? 4. Obtaining the active and passive right to vote for the Hungarian Parliament, for the purpose of influence in the preparation of a new vagrancy law to be issued with the greatest possible consideration of the free movement of persons.

Source: [No Author]. (1879). [No Title]. Kikeriki. Humoristisches Volksblatt, 1879, September 18, p. 2. Prepared for publication by Elena Marushiakova and Vesselin Popov.

\subsubsection{The Times Newspaper}

The Gipsy Congress

The Pester Lloyd reports that a congress of Hungarian gipsies was held in the early days of September at the village of Kisfalu, near Kaschau [1], but no details of the proceedings had as yet come to light. A principal subject of deliberation was known to be "the consideration of the common interests of gipsies everywhere". So far as is known only one such "common interests" had been discussed. It is well known that at such gatherings "hearth alliances" are contracted among many of the parties present. On the present occasion, there was a lively debate on this point, but with what result has not transpired.

\section{Notes}

1. Today Košice in Slovakia.

Source: [No Author]. (1879). Gipsy Congress. The Times, 1879, September 29, p. 7 .

Prepared for publication by Elena Marushiakova, Vesselin Popov and Aleksandar Marinov.

\section{Comments}

The case with the so-called Gypsy Congress which was allegedly held in 1879 in Kisfalu is a typical example of media mystification, perpetuated from one newspaper to another, even reaching The Times newspaper in London which, at the time, had been regarded as the most authoritative newspaper in the world. From here, the 'Gypsy Congress' in Kisfalu becomes a 'real' event that is also included in academic literature (Hancock, 2002, p. 114). Verification of the sources has shown that the notice, which has been identified 
as original, allegedly published in Kaschauer Zeitung, does not in fact exist. This means that The Times newspaper has also played its part in this sensationalisation because no notice regarding a Gypsy Congress in Kisfalu has been published in the Pester Lloyd either.

The notices for the nominally passed (or upcoming) World Gypsy Congresses are not a rarity during that era. The first demystified case is from 1871 when the StuttgartnerZeitung played a trick announcing that a Gypsy parliament would be held in Bad Cannstatt, in Germany; in January 1872, The Times in London published a notice about this parliament, as did the Evening Standard a month later. These notices have been used as a basis for the construction of the new Roma national historical narrative. The "International Congress in Darmstadt", was proclaimed to mark "the birth of the modern pan-Romani movement", underlining that it was attended by delegates from Germany, Spain, Italy and Russia (Puxon, 1975; quoted in Klímová-Alexander, 2005, p. 159). Later, however, the origin of this notice in a joke in the context of the annual Würtemburg Festival has been revealed (Hancock, 2002, p. 114; Klímová-Alexander, 2002, p. 108; 2005a, pp. 158-159; Kenrick, 2007, p. 38).

'The Gypsy theme' itself was a very curious one for readers at the time, because of the stereotypical public images of the Gypsies and because the messages for a forthcoming unification of all Gypsies of the world (which was the aim of the represented imaginary events) guarantees the attraction of a great readership. Much more interesting is, however, the fact that all these doubtful notices in the press have been accepted without reservations, including by researchers, not only during that period but even nowadays. The already mentioned doubts about the veracity of the International Gypsy Congress during 1879 in Kisfalu (Klímová-Alexander, 2002, p. 108; 2005a, pp. 158-159) are usually not taken into consideration. After all, at the base of the above-described mystification lies something real it reflected in the newspapers the occurrence of an annual meeting of "Upper Hungarian" (i.e. mainly from the lands of today's Slovakia) Gypsies. At this meeting, marriages were being arranged as well as other important matters for the society, which was a traditional practice among a number of nomadic Gypsy groups who met at a number of different places in Central and especially in South-Eastern Europe. The reports in Epoche and The Times newspapers ironically hint that the "common interests" of the Gypsies are connected only with "hearth alliances" and weddings but no one paid attention to this so far.

Elena Marushiakova and Vesselin Popov

\subsubsection{The Letter of Raphael to Emperor Francis-Joseph}

Hungarian Gypsy offering to prove that he descends from "King Pharaoh"

The French newspaper, Le Temps, contained in its number of the 1oth September 1888, under the head "Autriche-Hongrie", the following paragraph, which I re-translate into English:

"A correspondent from Vienna to the Daily News says that an old Gypsy named Raphael has addressed a request to the Emperor Francis-Joseph, in which he begs him to proclaim him King of the Gypsies because he can prove his direct descent from 'King Pharaoh'. The 
subscriber of the address promises on his part to put an end to the vagrant habits of the Gypsies, and so enable them to furnish good soldiers to the Austrian army." [...].

P. B. $[1]$

Source: P. B. [Paul Bataillard]. (1889). Hungarian Gypsy offering to prove that he descends from "King Pharaoh". Journal of the Gypsy Lore Society, 1 (5): 305-306.

Prepared for publication by Elena Marushiakova and Vesselin Popov.

\section{Notes}

1. In all likelihood, the author of this text, signed with the initials P. B., is Paul Bataillard.

\section{Comments}

The existence of the so-called Gypsy Kings (or Barons, Dukes, Counts, Lords, Captains, Voivodes, etc.) is a well-known phenomenon since the very arrival of the Gypsies in Europe and it has been widely spread in many countries and regions across the continent during the Middle Ages. The first historical record about a recognised, by the authorities, chief of the Gypsies is from the island Corfu (at the time part of the Venetian Republic) during the second half of 14th century (Soulis, 1961, pp. 157-158). The 1423 Safe-Conduct is wellknown, issued by the Sigismund, Holy Roman Emperor at Spiš Castle (today in Slovakia), to Ladislaus, the Voivode of the Gypsies, as well as a number of other similar Safe-Conduct letters in Western Europe during the same period (Fraser, 1992; Kenrick, 2007), with which some sovereign rights of the Gypsy leaders over the respective Gypsy community and their independence from other local authorities have been confirmed. Subsequently, to these rights were added obligations wherein these leaders had to collect taxes and charges for the monarchs. These Gypsy leaders and representatives to the authorities have been referred to in various ways, for example, Król (King) in Poland and the Grand Duchy of Lithuania during 17th-18th centuries (Danitowicz, 1824, pp. 98-10о; Каманин, 1916, pp. 109128; Ficowski, 1985, pp. 32-59; Mróz, 2001, pp. 188-219); Ataman in Ukraine (as part of the Russian Empire) in 18th century (Плохинский, 189o, pp. 95-117; Беліков, 20о2, pp. 64-72); Çeribași in the Ottoman Empire from 16th-19th centuries (Marushiakova \& Popov, 2001, pp. 39-41); Knez or Kmet in the 19th century in Serbia (Ђорђевић, 1924, pp. 122-23); Jude/ Juge, Vataf, Bulibasha in Wallachia and Moldavia (Achim, 2004, pp. 61-65), etc.

All these "Gypsy Kings" have been officially recognised and/or assigned by the authorities; they have been a product of the Middle Ages and reflect the inclusion of the Gypsies in the already-existing social relations during the era of feudalism (including also during its fall). Raphael's request, however, is a phenomenon of another character, a product of the modern epoch and the time of the birth of modern nationalism. There are no historical data on what has been the result of the request of "an old Gypsy named Raphael" to the Emperor Franz Joseph I. However, it could be easily assumed that the request has not been taken seriously or that it has received no attention. That could be thoroughly explained keeping in mind the common societal positions towards the Gypsies at the time, characterised with disregard of these people perceived as being of lower social status and not comparable with the rest of the "civilised" European nations. 
In the presented material, there are two main points that deserve special attention. Firstly, that is the will to end the Gypsies' travelling way of life. Since about a century before, the situation had been radically opposite - Empress Maria Theresa and Emperor Josef have pursued a consistent policy regarding the Gypsies, one of its main pillars being the forced sedentarisation of the Gypsy nomads. Understandably, in the end, this policy has turned to be generally unsuccessful and the travelling way of life of part of the Gypsies in the Austro-Hungarian Empire continued. In the new societal conditions of the modern era, however, separate representatives of the Roma elite (in this case, Raphael, of whom nothing else is known) obviously reached a new vision for the future of their community and for the need of its social integration. According to him, a necessary condition for the success of such integration is the seizing of the travelling lifestyle. That is no historical curiosity, as it would be understood later since similar processes would subsequently take place among Roma elites (in the 2oth century) in other countries of Central and Eastern Europe.

Secondly, the proposal to include Gypsies in the army is of interest. On the one hand, engaging Gypsies in the army can reasonably be seen as a manifestation of repressions, especially when it is committed violently (during the Middle Ages, in Western Europe there are many cases when Gypsies were forcibly and violently recruited in the military). In this case, however, the inclusion of the Gypsies in the army could be understood as a means of achieving an equal societal position, i.e. turning the military service of the Gypsies into their civil responsibility, similarly to everyone else, is seen as a sign of them becoming rightful citizens.

Also interesting is Raphael's reference to "King Pharaoh", to which he describes himself as his heir. The explanation for this is in the popularity among the Gypsies at the time of the idea concerning the Egyptian origin of the community. As the author of the published text writes, the name Faraonépek (People of Pharaoh) was popular in Hungary at the time. The very character of 'King Pharaoh', as the narrative about 'The Lost Kingdom' (most often Egypt) of the Gypsies has been widespread in the folklore legends with biblical motives among the Roma (Christian and Muslim) in the Balkans in the 19th and 2oth centuries (Ђорђевић, 1933, Vol. 7, pp. 122-133; Gjorgjević, 1934, pp. 26-32; Petrović, 1940, p. 112; Marushiakova \& Popov, 1994, pp. 23-30), and also elsewhere in Central and Eastern Europe (see e.g. Добровольский, 19o8, pp. 4, 53). One can find references to various motives and narratives about Pharaoh and Egypt in almost all chapters in this book. So, this reference in Raphael's address to Emperor Franz Joseph I is not at all accidental, and in the general context of the letter reflects the beginnings of the process of creating a new, national, historical narrative (a process characteristic at that time for all emerging nations in the region).

In fact, the actual beginning of these processes could be discovered in the work of a Hungarian Rom, namely Ferenc Sztojka Nagy-idai (1855-1929) and specifically in his epic poem A cigányok vándorlása (The Wanderings of the Gypsies), which created a new historical myth for the birth and the early history of the Gypsies (Nagy-idai Sztojka, 1886). The poem reflects on the arrival of the Gypsies in the Hungarian lands in the time of 
Attila the Hun (5th century). According to the poem, the Gypsies used to have their own fortress which even Attila was not able to take over. However, soon after that, great starvation spread and that is the stated reason why some of them began to travel, to separate into nine tribes, which practised different professions (pot making, horse-trading, commerce, metalwork, masonry and carpentry), spread around various Hungarian regions, while some others settled permanently. Sztojka well ahead of his time does not look on the 'exotic other', but attempts to formulate the Gypsies' own narrative as a Roma author (Orsós, 2015).

Elena Marushiakova and Vesselin Popov

\subsubsection{An Association of Gypsies}

Stowarzyszenie cyganów

W Budapeszcie zamierzają utworzyć cyganie wielkie stowarzyszenie, do którego będą należały wszystkie muzyki cygańskie. Na czele stowarzyszenia stanie pracownik pióra, który ma wydawać czasopismo. Redaktor ten otrzyma tytuł: "krajowy wajda cygański”.

\section{An Association of Gypsies}

In Budapest, the Gypsies intend to create a great association, to which all Gypsy music will belong. At the head of the association will be a pen worker who is to publish a magazine. This editor will receive the title: "National Gypsy Vajda" [1].

\section{Notes \\ 1. Hungarian term, i.e. Voivode.}

Source: [No Author]. (189o). Stowarzyszenie cyganów. Gwiazdka Cieszyńska, 189o, September 6, p. 362 .

Prepared for publication by Elena Marushiakova and Vesselin Popov.

\section{Comments}

This is the first historical evidence of the emergence in Central Europe, in the conditions of the Austro-Hungarian Empire, of a new, previously unknown there, social phenomenon - a professional association of Gypsy musicians. This turned out to be a lengthy process and the final legalisation of Magyar Cigányzenészek Egyesülete (Association of Hungarian Gypsy Musicians), led by Béla Radics, that took place only in 1908. The Association published the Journal Magyar Cigányzenészek Lapja (Journal of Hungarian Gypsy Musicians) in the period between 1908-1910.

During the Middle Ages in Western and Central Europe, Gypsies were not allowed to participate in the existing guilds system and were also forbidden to create their own. The situation in South-Eastern Europe is quite different, in the context of the Ottoman Empire, where local Gypsies fitted seamlessly into the Ottoman esnaf (guild) system (see below).

Elena Marushiakova and Vesselin Popov 


\subsubsection{A Letter to the Editor of the Macedonia Newspaper}

Прилеп, 3 юний 1867 година.

\section{Г-не Редакторе на “Македония”!}

Всички знаят защо най укорният помежду всички християнски населения е Егьупският народ, и той, според управлението на верата ни от фанариотите, не се приемват точно в[ъв] всичките тайнства на православната вера. Но на това коя е причината, по-долу ке видите. Сега, ако прашат некои некого от фенерлиите що се и как се, готов е обикновенния от них отговор ке чуеш: че са управители на вярата, за което те само имат право, и последователи на Апостолите Христови. Но ако вземеш да [ги] изпиташ за нихните работи без друго ке ги найдеш самите гонители и разрушители на верата и на правилата й, и възползвайки се от кроткостта, простодушието и чистата красота на иноплеменниците, [те] употребяват за средство на нихното лукавство и интриги вярата, за да съзлечувает векът и го държат в ярем и робство, уничтожувайки сичките правдини, които са дадени от самаго Господа Нашего Исуса Христа, на сичките долу под небето, които повервуваших в него и се кръстят в името му. “Елици во Христа крестистеса во Христа облекостеса” (Галат., гл. 3, 27). Тия кажуват грамогласно, че всички народи, които изповедуват православната вера, требва непременно да са подчинени под духовната власт на гърците, и нема никой никакво право да има свое духовно началство, за кое[то] толку прения се сториха и уще и до днес се правят с Българите, които си бараят справедливо правдините, които им се дават не само от самите Апостолски правила, правейки повече от едно колку-що се изискува за един предмет число вишегласие, и даже и тия, що преди време си имаха. А гърците постоянствуват в упоритостта си и кажуваят, без да се помислят в кой век живеят, че благоволно бидейки по дух святому, те да просвещават народите, право имали и да ги стрижат (владеят). За чудо! Как не се посрамуват, кога изкажуваят и печатно едни такива безсловестности, когато и най-простите знаят, че в Апостолите Христови, които биха определени за да просветят народите с Христова вяра, ни имаше ни един Еллин, и по това ясно се вижда, що не било на Еллините по благоволение духу святому да просвещават народите? Па ако да бяха биле, како те ще кажуваят, само те приятни Богу, а всички други подозрени и ничтожни, то защо чрез Дух Светий говорят Апостолите всичките езици и не само Еллинския, и да проповедуваят както що сам Исус им заръчва - “Шедше во мир вес проповедите Евангелие всей твари.” (Мар., гл. 16, 15), а не само на Еллините. Сега, като виждаме, че Еллините нито са биле избрани по благоволение [на] Светия Дух да просвещават народите, ни па са биле самите те приятни, угодни Богу [...], то защо, ако са биле истински подражатели на Христовите правила, да кажуват, че те имат право да началствуват над всичките православни народи и да са нихните интриги иим потъпкуваят правдинето и [да ги] държат как за свои роби, или срамотно да го речем, как свое имане (хайване)?. 
От тука нека забележи човек, в колко бедно състояние се намира Великата Черква. Но това не е нищо за друзите народи като Българите и пр. според нас Егупците, които достигнахме до една най жалостна степен низости и да не можеме никога да се одързостиме да изправиме едно помежду нас образование, отчаяни бидейки от управлението на църквата, кои ни доказаха и съборно, че не сме приятни Богу. Коя е причината що един Егуптянин служит същевременно на два и на три вероизповедания? То без друго е що бидейки той християнин и видувайки що в[ъв] всичките тайнства не е прият, а най-вече и това що се подозрева от другите християни, то прибегнува и към друго вероизпоедание, чувайки си обаче и първобитното си. И така разтурени бидейки Егьупците, и кой в тръне, кой в глог, и в едно ужасно отчаяние не могат да направят общество и да се погрижат за едно образование. Това истото ке го найдеш и [в] Българите; но благодарение на обстоятелството, че те дочуваха (довардиха) и що беха друзы за них, а па инакви за нас. Това истото го видохме и в[ъв вестник] “Гайда” от бр. 15 от год. III, къде докажувайки за нашето прозхождение, че сме порода от старите Египтенци, за кое живо докажуваят не само нашето преимущество и способности, но и самият ни език, и самата дочувана и до днес произвиска “Егупци”, а от друзы “атиняни-атнингани”, а цигани, велит, че Св.Григ[орий] Омиритски ни возбранил свещенодействието. Това е що нам ни отхвърлило в отчаяние и ни направило така как що сме днеска, как можало така да бедят вера полухристиянин и полунехристиянин, или в кое правило [да] го найде Неговото Светейшество, та кажува, че Егупците били съвършенно неприятни Богу? Ако Негово Светейшество се основавал че Егуптянците по причина, че мъчиле някогаш Израелтяните га били грешни и не те приемват в християнската вера точно закона, не може ли да видят що велит [Евангелието,] 2 Коринт., гл. 5, 17 - “Аще кто во Христу нова тварь: древняя мимоидоша, се быша вся нова”. Защото ако не беше така, то трябваше и самите Юдеи и даже Апостолите да бъдат подозрителни кога всекога почти се показваха противници [на] Бога, за кое[то] много пъти беха под наказание, и освен това и самите пратени от Бога пророци избиха, най-после и възлюбленият Негов Син на кръста распнаха. Но “Бог слезе да спаси грешните" (1 Тим., гл. 1, 15). [...].

Но как[вото] що било, или от незнание или от някакви особени капризи и вражда, що хранел Негово Светейшество на Егюпците, та от яда да си отмъсти им забранил свещенодействието, то защо последователите Апостолски да го отхвърлят, виждувайки, че работата е що принадлежит дивяците - идопоклонници да вероваят, не уще с по-голяма деятелност го потвердваят? Не те ке се извинат що не могат едно влакно да изменят от това, що им се оставиле св.Отцы; на това ке им дадем правото, ако да са истински подражатели апостолски; но освен що не е работата апостолска, найпаче противоположна, виждаме че всичко що е в полза на гърците, макар от кого да е измислено и указано, го прибират и не го припущаят, а все що не е за в полза них, сиреч що е противоположано на нихните високи идеи и дават различност на всичките народности в християнската вяра, макар да е от самаго Исуса Хр[иста] и от Апостолите узаконено, кат[то] що велит - "Несте Юдеи, 
ни Еллини, несте ни раб, ни свободен, несте мужеский пол, ни женский, вси бо ви единно есте в Христе Исусе" (Галат., гл. 3, 28) - не го признават и се чинат глухи като [че] не го знаят; и други много [примери], за които не ми е речта [сега] да ги изследовам.

Сега да питаме: коя е целта на гърците, що не дават на другите народности вероизповедни права и ги унищожуваят енергически? Колко[то] за другите народности, как[то] например Българите и пр., не само немам толкова способности, за да издирвам очевидното на гърците интригуване, за което е толкоз пъти вече доказано, но и това що предмет на моето говорение е друг. Аз сакам да докажем за Егюпците, за които никой до днес ни е обърнал внимание, нито па някой от нас се е съвестил да са об[о]зри къде се нахождат, коя е причината що толко[3] са потурнати вероизповедно, от кое[то] произхождало после и нравственото [ни] боледувание. Доказано е, защо пред[и] 18оo [години] пр. Р. Хр. живееха в днешната Еллада народ Еллински, толко[3] див и свиреп, живящ в гори, колиби и пещери, хранещ се с[ъс] землени корени и някои прости диви растения, що не знаеше ни ба, ни итру.

В това истото време, кога[то] Еллините бяха дебелаци, и по нашему - пасеха трева, Егюпците бяха стигнали до една висока степен [на] образованост, [но] направиха някои смущения в Египет. От кое[то] недоволствуваха няколко хилядно число [хора и] се преселиха в Еллада. Там, в Еллада, донесоха заедно с всичките си изкуства и писменност, но и Еллините - дивите, с неуморните старания на Егюптенците да ги просвещават, възлязоха в един ред да се поизпитомяват и така постепенно сродявайки се ся с просветените им гости, които се заселиха в Атина [Атика], къде се направи от предводител Кекрепс [и] главний град Атен [Атина], от което приеха после името Атиняни, Ацингани, [и] достигнаха колко-годе съвършенно според другите народи, живеещи в то[в]а време, степен [на] образованости. И така по [това] време разпространи ся просвещението по другите страни, за кое[то] гордите днес гърци кажуват, че те са просветители на Вселена[та]. Имайки си прочие на ум, гърците кога да е, бавно или бързо, трябва да разбере светът, че не от них се [е] разпространило просвещението, с което да се гордеят, ако някак останат остатки от Египтянците, които от после пострадаха [от] едно опасно изменение в политическият им живот, като се разпространиха по Вселена[та], които възползувайки се от обстоятелствата да не се поопулат, и после с нихното нравствено събудование, се докаже [на] мира, що Еллините лъжат с това що кажат, че те просветили Европа, ами Егюпците, както що самите них просветиха, това подбуди Еллините, да нападнат Егюпците вероизповедно до толку, щото омразни бидейки на секого, да се $[\mathrm{x}]$ върлят в отчаяние и се изгубят съвсем от земното кълбо, за да не пречат в очите на Еллините, за което и сполучиха. Тяхна е причината щото Св. Омиритский възбранил на Египтияните свещенодействието. Как не се засрамват гърците да крескат по всета Европа, че по причина, те що били причина да се просвети Европа, трябва да имат европейците за свои благодетели [гърците] и да им спомогнат в случай [на] нужности, а те - Гърците, на своите благодетели и просветители не само що не им спомагат в бъедното им състояние, но още и ги погазуват. Нека 
се позачервенеят малко и нека онемеят! Ако сакат да се гордеят пред Европа, че те са им просветители, нека дойдат първо да се приклонят и припаднат пред нозете наши, за да си припознаят своите просветители, и си изполнят длъжността си, с което да покажуват перв пример на другите, че тогай имат право в исканията си.

Един Егюптиянин

Prilep, June 3, 1867 .

\section{Mr. Editor of Macedonia!}

Everyone knows why the Egyptian people are most reproached among all Christian peoples and they, according to the way the Phanariots [1] govern our faith do not change exactly in all mysteries of the Orthodox faith. But what the reason for that is you will see later. Now, if you ask someone of the Phanariots who they are and how they became such, you will hear the usual response, that they are governors of the faith and only they have the right to it and followers of the Apostles of Christ they are. But if you set to examine them about their affairs without others, you will find the very persecutors and destroyers of the faith and its rules making use of the gentleness, simplicity and pure beauty of the other tribes, they use faith as a means of their wile and intrigue in order to stop time and keep it in a harness and slavery destroying all righteousness which was given from Our God Jesus Christ to everyone down under Heaven who believes in Him and is baptised in His name. "for as many of you as were baptised into Christ have put on Christ" (Galatians 3: 27). They say loudly that all peoples of the Orthodox faith must be under the spiritual power of the Greeks and no one has the right to have their own spiritual masters, for which so many wrongs have been done and are still being done today with the Bulgarians, who protect their rights justly, which rights are given to them not only from the Apostle's rules but also some rights which they had before. And the Greeks persist in their stubbornness and say without thinking about the century they live in, that being in the grace of the Holy Spirit they had the right to enlighten the peoples and rob them openly. How are they not ashamed when they say and print such unspeakable things, when even the most simple people know that among the Apostles of Christ whose task was to enlighten the peoples in the faith of Christ there was no Hellene and this clearly shows that it was not up to the Hellenes to enlighten the peoples with the grace of the Holy Spirit. But if only they were, as they will say, pleasant to God, and all others suspicious and unworthy, why is it then that the Apostles speak all languages through the Holy Spirit and not only the Hellenic and preach as Jesus told them: "Go into all the world and proclaim the gospel to the whole creation." (Mark 16: 15), and not only to the Hellenes. Now when we see that the Greeks were neither chosen with the grace of the Holy Spirit to enlighten the peoples, nor were only they likable and pleasing to God [...], why if they are true followers of the rules of Christ, they say that they have the right to govern all Orthodox peoples and interpret rightly their intrigues and they would them keep as their slaves or say it shamefully - as their property (livestock)? 
Let one see here how poor the situation of the Great Church is. But this is nothing for the other peoples like the Bulgarians and for example the Egyptians, that we have come to such a pitiful contemptibility so we can never gather courage and make our own education, since we are desperate from the rule of the Church which has shown us from its councils that we are not pleasing to God. What is the reason for an Egyptian to obey two and three faiths at the same time? It is because he, being a Christian and seeing that he is not allowed into all the mysteries, and mostly that he is suspected by the other Christians, resorts to another faith and yet preserves the primary one. And thus, the Egyptians being dispersed and being out of the frying pan and into the fire, and being in terrible despair, they cannot make a society and take care of education. You will find the same thing among the Bulgarians, but owing to the circumstances that they have preserved themselves as Christians and that they had friends among them, and none with us. That same thing we saw in Gayda in number 15 [2] from the year III, where proving our origin, that we are a breed of the old Egyptians, which it is proven lived not only by our advantage and abilities but by our very language, and the appellation "Egyptians" which we still hear today and from others "Athenians-Antinganians", a Tsigani, and some say that St Gregory of Omirits forbade officiation. This is what has driven us to despair and made us the way we are now, how could we be semi-Christian and semi non-Christian in faith, or in which rule should His Holiness find it to say that the Egyptians were completely unpleasing to God? If His Holiness had based his evidence on the fact that the Egyptians once tortured the Israelis [3] who sinned and did not accept the Christian faith, could he not see what said The Gospel "Therefore, if anyone is in Christ, he is a new creation: The old has passed away; behold, the new has come!" (2 Corinthians 5: 17). Because if it were not so, then the Judeans and the Apostles should have been under suspicion when almost always they were adversaries to God, for which they were punished many times and besides, they killed the very prophets sent by God and finally crucified His beloved son. "Christ Jesus came into the world to save sinners" (1 Timothy 1: 15). [...]

But whichever way it happened, either from ignorance or from some peculiar whims and hostility that His Holiness felt for the Egyptians, and in his anger to punish them he forbade officiation, so why should the followers of the Apostles reject it seeing that it belongs to the savages - idolaters believing, do they not confirm it with yet more activity? Yes, they will apologise that they cannot change a fibre from what we have left them; we will give them this right, even if they are true followers of the Apostles, and not only this is not the duty of the Apostles but is exactly the opposite, we see that it will all be in benefit to the Greeks regardless of who invented it and ordained it, they take it and do not let go, and all which is not in their benefit, that is which contradicts their lofty ideas and distinguishes all peoples in the Christian faith, though it was made legitimate by Jesus Christ himself and the Apostles who said - "There is neither Jew nor Greek, there is neither slave nor free, there is no male and female, for you are all one in Christ Jesus" (Galatians 3: 28) - they do not recognise it and pretend to be deaf as if they do not know it; and many other examples about which I am not speaking now to research them. 
Now let us see which is the purpose of the Greeks that they do not give rights to the other faiths and destroy them vigorously? As far as the other nationalities, as for example the Bulgarians and others, I not only do not have the abilities to seek the obvious interest of the Greeks which has been proved so many times, but the topic of my speaking is different. I want to prove about the Egyptians, to whom no one still pays attention, nor has someone among us been conscientiously thinking of where they are, what is the reason that their faith is lost, where our moral sickness comes from. It has been proved that 1800 years B.C. there lived in present Hellas a people so wild and ferocious, living in woods, huts and caves, feeding on earth roots and simple wild plants, who did not know anything.

At that same time when the Greeks were oafs and as we say were grazing grass [i.e. they are dumb - authors note], the Egyptians had reached a high degree of education, but they did some disturbances in Egypt. From which some thousand people were displeased and moved to Hellas. There, in Hellas, they brought together with them their eternal arts and alphabet, and also the wild Hellenes - with the tireless attempts of the Egyptians to educate them - acquired a more tamed order and gradually relating to their educated visitors who settled in Attica, where they made Cecrops the leader and main town Athens, from where they took the name Athenians, Atsigani, and reached a more or less perfect degree of education compared to the other peoples, living at that time. And thus, at that time, the enlightenment spread to the other countries, for which the proud Greeks today say that they are the enlighteners of the Universe. Actually the Greeks, keeping in mind that sometimes, slowly or quickly, the world has to understand that enlightenment they are proud of did not spread from them, if somehow remnants from Egyptians who later suffered from a dangerous change in their political life by spreading over the Universe, who using the circumstances, do not loiter and then with their moral awakening it is proved to the world that the Hellenes are lying in saying that they have enlightened Europe, but the Egyptians who enlightened them this incited the Hellenes to attack the faith of the Egyptians so much that being hateful to everyone they would sink in despair and vanish from the globe not to interfere in the eyes of the Hellenes, for which they have succeeded. Theirs is the reason that St Omirits forbade the Egyptians to officiate. How are the Greeks not ashamed to shout to all peoples that they were the reason for enlightening Europe, and the Europeans should have for their benefactors the Greeks and help them in case of need, and they, the Greeks, will not help their benefactors and enlighteners in their poor situation but will also trample on them. May they blush a little and may they lose their tongues! If they want to be proud before Europe that they are enlighteners, let them first bow and prostrate themselves at our feet, to recognise their enlighteners and do their duty with which to show a prime example for the others, and then they would have the right to ask.

One Egyptian

\section{Notes}

1. 'Phanariotes' - from the name of the neighbourhood Phanar (modern Fener) in Istanbul, where the Court of the Patriarch of the Eastern Orthodox Church resided and rich Greek merchants 
lived who influenced the Ottoman administration. It was used with a derogatory connotation for the Greek clergy and their followers (Greeks and Bulgarian) during the struggle for independence of the Bulgarian Orthodox Church from the Eastern Orthodox Church in the 185os and 186os.

2. A mistake of the author of the letter - it is meant here issue No. 17 of Gayda Newspaper, where Petko R. Slaveykov's article was published (Гайда, 1866, pp. 256-258).

3. The reference here is to the popular legends between the Gypsies in Bulgaria about the hatred between Gypsies and Jews, which is rooted in as early as Biblical times. According to these legends, based on the biblical story of Moses and the escape of the Jews from Egypt, Jews were the cause of the death of Gypsy King - Pharaoh and the collapse of the Gypsy Kingdom, i.e. Gypsies consider themselves descendants of the ancient Egyptians (Marushiakova \& Popov, 1994; 1995).

Source: Един Егюптиянин. (1867). [Писмо до редактора]. Македония, 1867, July 8, p. 3. Published also in: Marushiakova \& Popov, 1995, pp. 39-42.

Prepared for publication by Elka Mincheva.

\section{Comments}

This letter can be properly understood only in the context of the social movement of Bulgarians during this period against the Eastern Orthodox Church, perceived as the 'Greek Church', in an effort to have their 'own', independent national Bulgarian Orthodox Church. The newspaper Macedonia, where the 'Letter to the Editor' was published, was the main speaker on this movement, and its editor in chief, Petko R. Slaveykov, was one of its leaders. For the author of the letter, 'One Egyptian', and similarly for the Bulgarian national revivalists, these 'church' struggles were religious only as a form, but in fact, they were a movement for the protection of the fundamental right of every nation to religious and civil equality respectively. The author feels the disparaging attitude of the macrosociety towards Gypsies and suffers from restrictions imposed on his people by the Christian (and in general the religious) institutions of that time. In his letter, he shows the injustice of such an attitude both in terms of the essence of the Christian religion and in terms of the historical fate of individual nations. In defence of his theses about the 'historical right' of the 'Egyptians' to 'make a society and take care of education,' he uses the historical knowledge accessible to him. This is the article entitled 'Циганите' (Тhe Gypsies) written by Petko R. Slaveykov, published in Gayda newspaper in 1866, which actually inspired him to write his letter to the editor.

The content of the 'Letter to the Editor' confirms once again what we know from other historical sources. In the Ottoman Empire, the Gypsies were integrated into the social fabric with their own social and civil status, which was very similar to the status of other nations' subjects of the Empire. At the time of the Ottoman Empire, the distinction between Roma and current Balkan Egyptians did not exist: they were one community, called in the Ottoman Empire Kıbti (from the word 'Copts' in the sense of Egyptians) or Çingene. In the 'Letter to the Editor' the author uses the term Егюпuи (Egyptians in Bulgarian), responding to an article entitled Циганите (Bulgarian term for this community). These designations are encompassed into the English umbrella term 'Gypsies'.

So, the Gypsies in the Ottoman Empire who were full-fledged subjects of the Sultan have had civil rights since the $15^{\text {th }}$ century, unlike the Gypsies in Central and Western 
Europe who achieved this social status much later (Marushiakova \& Popov, 2001). As a result, the development of the Gypsies, at least on the level of ideas, was very similar to the development of the other Balkan nations among whom they lived. The letter shows that at least some members of the Gypsy community in the Balkans already in the 19th century reached a new stage in the development of their community consciousness. This new stage is characterised by exiting the 'internal' traditional frames of the community and seeking an equal place in the new 'external' socio-cultural realities, according to the norms and values that predominate. It is the Balkan context that determines the shape of this new public appearance of Gypsies - they, like other Balkan nations, are searching actively for proof of a 'glorious' historical past. They are questing for the creation of a new national historical narrative that will serve as support and argument in the struggles for their civic emancipation as separate but equal to other Balkan nations' communities.

As a whole the logic of Gypsies in Ottoman Empire in the Balkans development, as seen in the 'Letter to the Editor' is a repetition of the pattern of development of the other Balkan nations in the 19th century in all its segments - the creation of their own system of education, their own church with services in their own language, and eventually, without especially mentioning it, the implied perspective of their own state ('make a society'). Whether these ideas were altogether realistic and to what extent they resonated with the Gypsies themselves, in the view of their situation in the Balkans at the time is another question. However, the emergence of such ideas is a fact which cannot be ignored.

The question remains - who was the author of the 'Letter to the Editor'; who was the person who signs as 'One Egyptian'? The author impresses with his literature style and especially with his high level of literacy. From numerous references to theological literature and to the publications in the periodical press, it is palpable that the 'One Egyptian' was well educated for his time and particularly in relation to his peers. For a long time, he stayed anonymous, but the answer to this question is already known (see the published sources below) - he is Iliya Naumchev from the town of Prilep (today in the Republic of North Macedonia). It is worthwhile to discuss him further.

The exact dates of his birth and death are unknown. It could be estimated that he was born in the 185 os in Prilep. For many years, he has worked as a barber while at the same time he has been actively involved with his fellows for the uplifting of their civil consciousness (see below).

During the plebiscite conducted in 1873 , when the Orthodox population in certain areas of Macedonia had to choose to which church they should belong to (i.e. Greek or Bulgarian), Gypsies in Prilep (where Iliya Naumchev has been involved) and Bitola (where the Bulgarian municipality opened an initial school in the Gypsy neighbourhood), voted to join the Bulgarian Orthodox Church (Кънчов, 1901, p. 124). This has been a great surprise to the contemporaries (in large part, Gypsies in the Ottoman Empire were Muslim at the time). Iliya Naumchev himself was ordained a priest to the Bulgarian Exarchate based in Istanbul in 1885 (at that time Prilep was still part of the Ottoman Empire), but his confirmation by Exarch Josef was accompanied by some problems. The proposal to ordain him a priest was sent by the Bulgarian municipality in Prilep, to which 
the Exarch insisted on indicating the parish in which he would serve, as well as having the consent of the parishioners, and of all members of the Prilep Municipality (Кирил, 1969, p. 611). Such a requirement generally did not apply to all such proposals and perhaps has been due to the unusual nature of the case (a Gypsy to become an Orthodox clergyman). Although unusual, the case is not unique - the presence of Gypsy monks has been reflected in documents dating as early as the 16th century in the Ottoman Empire (Marushiakova \& Popov, 2001, p. 35). Apparently, the Prilep Municipality has fulfilled all the requirements, Iliya Naumchev has been ordained a priest and continued to work actively among the Gypsies. The last historical source that mentioned about him is from the end of the 19th century (Кънчов, 190о, p. 124).

Elena Marushiakova and Vesselin Popov

\subsubsection{The Guild Holy Days}

Еснафските праздници

[...] Ето списък на праздниците, които служат разните еснафи в Прилеп: 1. [...]. 21. Ковачкият - 18 януари, Свети Атанаси; 22. Ковачкият-цигански - 17 януари, Свети Антони; 23. Цигулари и хамали - 17 януари, Свети Антони.

[Note] 2. Тези цигански еснафи от скоро време приеха еснафска служба, както другите българи. Причината за това е един циганин, Илия Наумчев, бръснар. Този Илия Наумчев, като беше бръснар, ходеха при него по-свестни хора в бръснарницата, и от ден на ден се разви и позна народността [си], и не се срамуваше да се казва егюптин, понеже името егюптин го били взели, според него, от Египет. Този Илия имаше голямо желание да има от циганската народност свещеник. Много години минаха, а той все желаеше този чин да има у тях и непрестано работеше помежду циганите да ги поправи от пиянство и от всичките им лоши поведения. След като придоби влияние между циганите, убеди ги да служат трите еснафа Свети Антония. Преди 2-3 години сполучи сам да стане свещеник при Св. Екзархия в Цариград.

\section{The Guild Holidays}

[...] Here is a list of the holidays that the various guilds celebrate in Prilep: 1. [...]. 21. The one of the Blacksmiths - 18 January, St Athanasius; 22. Gypsy Blacksmiths - 17 January, St Anthony [1]; 23. Violinists and Porters - 17 January, St Anthony [2].

[Note] 2. These Gypsy guilds soon adopted the guild service, as do other Bulgarians. The reason for this is a Gypsy, Iliya Naumchev, a barber. This Iliya Naumchev, being a barber, was visited in his barber-shop by more diligent people, and day by day he developed and got to know his nationality, and he was not ashamed to say he is Gypsy, i.e. Egyptian, because the name Gypsy was taken, according to him, from Egypt. This person Iliya, had a great desire to have a priest from the Gypsy nationality. Many years passed, and he always wanted to have this rank, and he worked constantly among the Gypsies in order 
to keep them away from drunkenness and all their bad behaviour. After he gained influence among the Gypsies, he persuaded them all the three guilds to honour as their patron Saint St Anthony. 2-3 years ago, he succeeded in becoming a priest at the Holy Exarchy in Constantinople [3].

\section{Notes}

1. Gypsies in Bulgaria, as well as ethnic Bulgarians, celebrate as patron Saint of the Blacksmiths St Athanasius, i.e. in this case there was a shift of celebration of the Gypsy guilds holy day with one day after the traditional day (which remains as a holiday for the ethnic Bulgarian Blacksmiths). 2. It is noteworthy that the three Gypsy guilds have one common patron saint's day, which is unusual because the rule is that each guild has its own patron saint. In this way, the leading one is the ethnic criterion, not the professional one, and so there is one day that is a holiday for all Gypsies.

3. The ecclesiastical struggles ended with the establishment of a Bulgarian Exarchate, independent of the Eastern Orthodox Church. It was established with the special firman of Sultan Abdülaziz in 1870.

Source: Цепенков, М. К. (1898). Обичаи от Прилеп. In Сборник за народни умотворения, наука и книжнина. Книга 15. София: Министерство на народното просвещение, pp. 180-181. Prepared for publication by Elena Marushiakova and Vesselin Popov.

\section{Comments}

As already stated above, in the Ottoman Empire the Gypsies were, to say it with modern social and political terminology, full-fledged citizens. A typical example in this respect is the participation of Gypsies in the overall system of the 'esnaf', which is Ottoman Turkish term for 'guild', with the same meaning of powerful professional association for mutual aid, who controlled the practice of their craft in a particular town. Formally the Ottoman Empire regulated legally the activities of the guilds only in 1773, but the historical data (e.g. the list of esnafs in Istanbul, made on the orders of Sultan Murad IV (1623-1640)) shows that many Gypsies living in Istanbul, were members of different guilds already in previous century (Çelebi, 1967, pp. 207-336).

The ethnicization of the guilds in the Ottoman Empire in 19th century was directly related to general processes of ethnicization in the Empire and esnafs were part of the national movements of the Balkan peoples during this period. The first information about the participation of Gypsies in the existing esnafs dates back to the 18th century (Marushiakova \& Popov, 2016b, pp. 76-89). The Gypsy esnaf's organisations do not disappear with the end of the Ottoman Empire, and they continue to exist also in the newly independent states in the Balkans that arose during the 19th century after the breakdown of the Ottoman Empire. In the new conditions the esnafs transformed and modernised but continued to occupy an important place in the life of the community and determined its position in the society. Moreover, in particular in Bulgaria, the old forms of the Gypsy guilds acquired new and broader social dimensions and functions (see Chapter 3 ). Elena Marushiakova and Vesselin Popov 


\subsubsection{The Petition from Xanthi}

$$
\text { داخليه مكتى قلمى }
$$

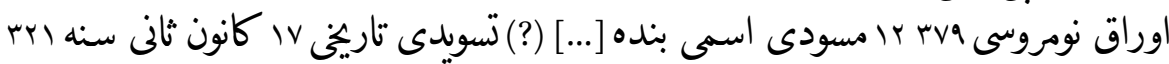

$$
\text { ادرنه ولايتى وكالت جليله سنه }
$$

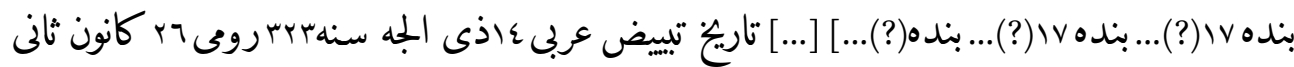

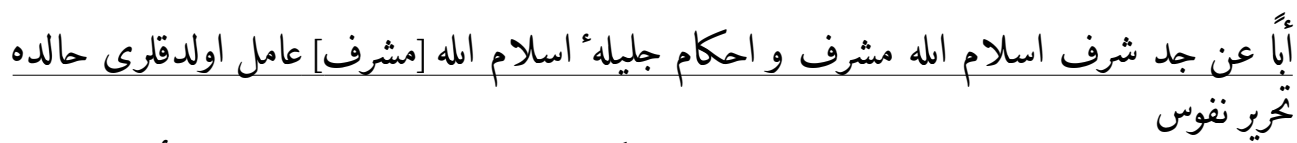
قوميسيونلرنه قبطى تعبيريله قيد اولندقلرندن و حالبوكم قبطى لقى [...] هندستاندن نشأت ايدن بر

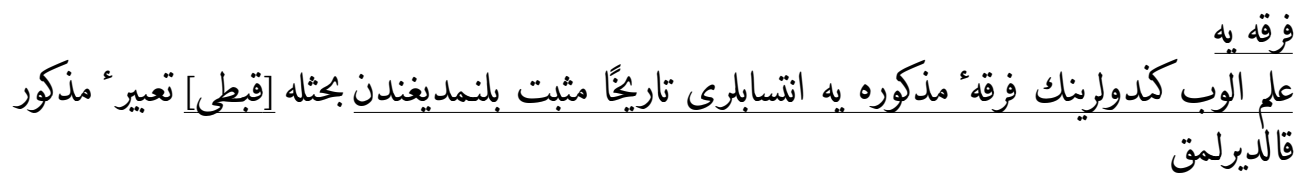
صورتيله قيدلينك اجراسى استدعاسنه و بعض افاداته دائراسكهِ قصبه سنك يرنارلق محله سى مختار و هيدرت اختيارية سيله اهاليدن طقسان طقوز كثينك مهرينى حاوى عدليه و مذاهب نظبه نظارت جليله سينه كوندريلوب توديع

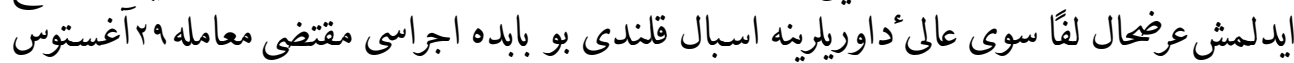
سنه I

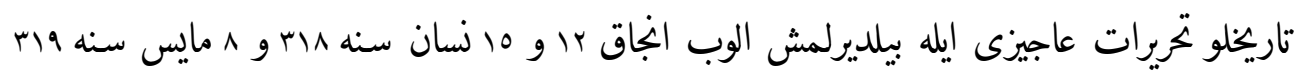
تاريخلرنده

عموم صره سنده تبلغ ايد لديكى وجهله بويله بر جوق مهره مهرى حاوى اوراق و محضر تتظيم وترتييله كوندرلمسنه ميدان ويرلمامسى لازم كله جكيندن خلاف تهن تبليغات معامله دن توقى ايدلمسيجيون ايكاب إيدنلر از سر نو وصايا ايفاسنه همم عليهُدستوريلرى دركار بيورلمق بابنده

Internal Affairs, Corresponding Secretary Office, Document No. 37912.

Who prepared the draft of this document Slave (2) ...(?) [1]. Draft Date January 30, 1906. To the Office of Edirne Province.

Slave ...(?) 17 Slave ...(?) 17 Slave ...(?) ...(?).

The Date of Preparation of the Fair Copy February 8, 1906 [2].

To the attention of the great governor: The attached petition is addressed to the high Ministry of Justice and Religions with the seals of ninety-nine individuals from among the inhabitants and the muhtar [3] and the board of aldermen of Pirnarlık neighbourhood 
in Xanthi [4]. That is about some explanations and the appliers' demand not to be registered as Kıbti. The petitioners argue that the census commissions registered them as $K \iota b t i$, although the dignity of Islam has dignified them, and they have conformed to the great canons of Islam for generations, and the term Kıbti indicates a group of people originating from India to whom their belonging is not a historical fact [5]. I have already declared the required action in this context with my letters dated September 11, 1905 . On the other hand, as announced among the other issues on April 25 and 28, 1902 and May 21, 1903, prevention of preparation and delivery of such documents and petitions with many seals is necessary, and for the avoidance of such illicit transactions, the great governor has to soon re-advice the ones whoever needed.

\section{Notes}

1. In the translation of the original text, the Ottoman-Turkish dictionary by Devellioğlu (2013) and Kubbealtı dictionary by Ayverdi (2016) was used for the reading of individual words in the document. During the translation, the main intention adopted was the reflection of whatever present on the document to increase the practical functionality of the act for reader. The reader can recognise the indecipherable or uncertain writings on the document as they are emphasised by a question mark and thus reinvestigate the original document.

2. The original term is بنده (bende), which was an expression written by the Ottoman bureaucrats above their signs on the official documents, as a manifestation of their respect and dedication to the superiors (Pakalın, 1971, p. 202).

3. In the 19th century, the Ottoman state introduced a new administrative body on the base of mahalle (neighbourhood): primary and secondary muhtars (muhtār-ı evvel, muhtār-ı sān̄ī), initially in Istanbul and then in other regions, and in order to manage population movements, assigned muhtars to prepare cilm ü haber, a document including personal data on the residents who demand murūr tezkiresi, a permission document for free travelling (Çadırcı, 1970; Alada, 2008, pp. 183-185). In Christian neighbourhoods (and also in Gypsy neighbourhoods), a kahya superintendent and a muhtar were responsible for the mentioned tasks (Karpat, 2002, p. 257).

4. Xanthi (İskeçe or Eskice in Turkish) is today in Northern Greece, was located in Edirne Vilayet during the late-Ottoman period (Akbayar, 2001, p. 81; Sezen, 2006, p. 253).

5. The sentence is underlined in original.

Source: DAB: DH.MKT.628.64.18.2.

Prepared for publication by Egemen Yılgür.

\section{Comments}

The petition mentioned in the document above proves that the inhabitants of Prrnarlik (or Pirnalık) neighbourhood in Xanthi, which, even today, is reputed to have a high concentration of Gypsies (Aarbakke, 2000, p. 94) as early as 1905 were aware of the theories on the Indian origin of Gypsies. Ottoman elites whose former imagination of Gypsies was a blending of two descriptive discourses, travelling family groups with an uncertain origin (Yllgür, 2018a, pp. 276-277), or a cursed descent of Egyptians (Ulusoy, 2013, pp. 248), gradually imported that "new" (from 18th century) Western account of Gypsies and thus the Indian origin could be mentioned in the 19th century Ottoman texts (Vefik Paşa, 1876, p. 486; Mithat Efendi, 20o9, p. 10; Sâmi, 2015, p. 517). The document proves that this awareness was never confined to the Ottoman intellectuals or ruling elites at 
the beginning of the last century, but included the ordinary subjects of the Empire or, moreover, the ones who themselves were denominated as Kıbti.

In the last half of the 19th century, the Ottoman ruling elites revised their policy regarding Gypsies, whom the state registered as Kıbti for hundreds of years and levied a specific tax of fixed amount and exempted even the Muslims from conscription (Ginio, 2004; Ulusoy, 2011; Çelik, 2013). A short while before the Russo-Turkish War of 1877-78, the state cancelled the exemption of Muslim Kibțīs from the conscription and their liability to pay a specific fixed-tax (Paspati, 1888, p. 4; Yüksel, 20o9, pp. 84-87; Ulusoy, 2011, p. 131; Yılgür, 2018a, pp. 267-302). In the 188os, the state abandoned the policy of Kıbtis special registration and registered them among the other Muslims. However, in 1905, the category of Muslim Kıbti was re-introduced into the census terminology and this decision triggered their reactions (Yüksel, 2009, pp. 84-87; Yllgür, 2018b). The expression of their discontent of the old policy's renewal by sending petitions to the authorities was not exceptional. Emphasis on self-loyalty to the Islamic principles, or the state was constant in these appeals as is in the above example. What makes significant the mentioned case is the incorporation of recent historical theories by the inhabitants of Pirnarlik into the discourse utilised to reject any link between themselves and the Kıbtîs of the assumed original descent, whom the Ottoman intellectuals and the state at least partly came to conceive of as a people that are the survivals of an ancient migration from India, instead of an aggregation of non-pastoral and mobile family groups; or cursed Egyptians. Moreover, the petition exemplifies an attitude, which has been prevalent among them to deny exonyms such as Kıbti or 'Gypsies' as well as adopting more prestigious religious (Muslim) or ethnic (Turkish) identities (Marushiakova \& Popov, 1999, pp. 81-89; 2015, pp. 26-54).

Egemen Yilgür

\subsection{The Russian Empire}

\subsubsection{The Sorochyntsi Uprising \\ И[гнатий $]$ Н. Антоненко}

Ракирибэн ваш 1905 бэрш

Дрэ 1901 бэрш мэ пирдал пэскирэстэ дадэстэ удыкхьёмпэ дрэ форо Полтава писателёса В[ладимир] Г. Короленко. Дрэ одова же бэрш миро дад мыя, семья амари джиндя дрэван чёрорэс и амэнгэ бут помогискирэлас ловэнца писателё. [...]

Адай мандэ залыджияпэ писателеса бари дружба. Ангил сарэстыр ёв высыклякирдя ман лылварипнаскэ (тэ гинэс, тэ чинэс), а отэнчя дро 1902 бэрш лыя тэ дэл мангэ ваш распространениё соцыал-деморатическа прокламацыи.

Ёв адякэ мангэ ракирдя, коли дэлас прокламацыи:

- Окэ мэ дава тукэ запхэндлэ (запрешшёна) лылорэ, савэнца банго тэявэс прэ стрэга. Никонэскэ на дэ лэн дро васта, а тольки чюрдэ пиро кхэра, тэло удэра.

Мэ кэравас адякэ, сыр ракирлас В. Г. [Короленко]. 
Екхвар мэ шукар прогиндём екх прокламацыя и отэнчя пхэндём писателескэ:

- Ах, коли-бы адава тэ додужакираспэ сыгыдыр. [...]

Мэ прилыём дрэ годы советы писателёс и лыём лэстыр нэви пачка прокламацыи, гыём лэнца пирдал набут дывэса дро гав Ковалёвка. [...] Сыго захачия крестьянско восстаниё дрэ Ковалёвка и Карловка. Восставша розмардэ и роспхагирдэ рангирэ фелатиня. Бичядэ одорик ваш усмирениё драгунэн, ёнэ зачингирнас гаджен жыко мулыпэн чюпненца. [...]

Дрэ угыём дро Белгородо, Курско губ. Семья мири пиригыя дро гав барэ Сорочинцы. [...]

Мэ адалэ прокламацыи росчюрдавас дро Сорочинцы. Дро начяло 1905 б[эрш], коли дро Сорочинцы лыя тэ откэрпэ подпольно буты машкир кружкэндэ гаджендыр и мэ лыём тэ прилав учястиё дро адая буты. Коли же дро ноябрё 1905 б[эрш] дрэ амаро гав создыяпэ гаджендыр союзо, то мэ сомас выкэдымэ екхэса уполномоченнонэса адалэс союзос и учястиё прилавас дро заседании активос дро выкэрибэн программа, сави отэнчя - дро концо ноябрё исыс бичяды дро газеты и исыс напечятано.

Ангил восстаниё дрэ амаро гав и дро само востаниё мэ сомас дрэ одова кружко, саво правиндя сарэ бутяса восстаниёс. [...]

Мэ пробестём бутыр бэршестыр и сомас про сэндо кхэтанэ ваврэ товаришшенца, сэндындя Харьковско судебно палата.

Сэндо ман оправдындя.

Ignatiy N. Antonenko [1]

Speech about 1905

In 1901, through my father, I met in the city of Poltava with the writer Vladimir G. Korolenko [2]. In the same year, my father died, our family lived very poorly and the writer helped us a lot with money. [...]

Here I had a great friendship with the writer. First of all, he taught me literacy (read, write), and then in 1902 he began to give me social-democratic proclamations for distribution.

He told me so when he proclaimed:

- Here I give you the prohibited (forbidden) leaflets with which it is necessary to be on guard. Do not give them into someone's hands, but just throw them near houses, under the door.

I did as V. G. Korolenko told.

Once I have carefully read a proclamation and then told the writer:

- Ah, if only this happens sooner, I cannot wait for this. [...]

I kept in mind the advice of the writer and took from him a new packet of proclamations, went with them a few days later to the village of Kovalevka [3]. [...] A peasant uprising quickly erupted in the villages of Kovalevka and Karlovka [4]. The rebels broke and 
ruined the estates of the noblemen. Sent there to pacify them, the dragons have slaughtered the peasants to death with whips. [...]

After that, I went to Belgorod, Kursk governorate. My family moved to the village of Big Sorochyntsi. [...]

I threw those proclamations [also] in the village of Sorochyntsi [5]. In early 1905, when the revolutionary activity began to arise among the circles of peasants in Sorochyntsi, I began to take part in this activity. When in November 1905 a peasant union arose in our village, I was elected as one of the commissioners of this union and took part in the meetings of its leaders, in the development of the program, which was then sent to newspapers and printed at the end of November.

Before the uprising in our village and during the uprising itself, I was in the circle which ruled all the activities of the uprising. [...] [6].

I stayed in jail for more than a year and was at the trial together with other comrades, the Kharkiv Court of Justice judged us.

The court acquitted me.

\section{Notes}

1.The text was submitted for publication in the journal Nevo Drom by Nikolay N. Pyzhov, head of Sorochyntsi Uprising, author of books with memories of the uprising (Пыжов, 1929; 1930). The translation into the Romani language was done by Mikhail Bezlyudskiy.

2. Vladimir Korolenko (1853-1921) was a famous Russian writer, journalist, publicist and public figure, closely linked to the revolutionary movement in Tsarist Russia.

3. Today Kovalivka - a village in Poltava rayon, Poltava oblast, Ukraine.

4. Today Karlivka - a city in Poltava oblast, Ukraine.

5. Sorochyntsi (today Velyki Sorochyntsi) - a village in the Myrhorod region, Poltava region, Ukraine, the birthplace of the famous Russian writer Nikolay V. Gogol.

6. Long sections of the text have been omitted, including a description of the Sorochyntsi Uprising in 1905 (for more details see below) and of the active participation of Ignatiy N. Antonenko in it.

Source: Антоненко, И. Н. (1931а). Ракирибэн ваш 1905 бэрш. Нэво дром, An. 2, No. 3, pp. 12-15. Prepared for publication by Elena Marushiakova and Vesselin Popov.

Translated by Viktor Shapoval.

\section{Comments}

Reaching a certain degree of social integration of the Roma community (or parts of it) in the Russian Empire found its expression in the inclusion of some of its representatives in the social and political struggles. The fact that this occurred in Ukraine is, to a certain extent, natural in terms of the internal heterogeneity of the community, which is reflected in the varying degrees and varied forms of social integration of its individual divisions and parts. At that time, in Ukraine lived mainly Roma from the Servi group. Some of the internal divisions of the Servi continued to lead an active nomadic way of life in the early 2oth century, both in Ukraine and in Russia (nowadays they often define themselves as Voronezhskye Servi, but, rather than just the region of Voronezh, they live in a much wider area). In Ukraine itself, large parts of Servi live in villages (a few families per village), many 
of whom have almost entirely lost their language, and their mother tongue is Ukrainian. Their traditional occupation is blacksmithing (and along with this, they are often musicians), and are generally relatively well-integrated among their fellow villagers.

The beginning of the 2oth century in the Russian Empire was a time of sharp aggravation of socio-political struggles, which is reflected in the First Russian Revolution (1905-1907). The main organisers of this revolution were the parties of the far left - the Socialist-Revolutionaries (the so-called Esers), the Social Democrats (the so-called Bolsheviks and Mensheviks) and the anarchists. Part of this revolution was the Sorochynsk Uprising (December 1905 - January 1906), which became widely known thanks to the activities and publications of the writer Vladimir Korolenko. The uprising itself was organised by the already mentioned Nikolay Pyzhov, at that time an 18-year-old campaigner of the Social Democratic Party. After the brutal suppression of the uprising by the authorities with the help of Cossack troops, with many casualties (killed and wounded people), and shocked by the atrocities committed, Vladimir Korolenko published his journalistic investigation, entitled The Sorochynsk's Tragedy (Короленко, 1907, pp. 172-205).

Very little is known about Ignatiy Antonenko. In the studies devoted to the uprising, the name of Ignatiy Antonenko could be found, but without much details about him. For example, it is described how the writer Korolenko bailed five peasants arrested after extinguishing the uprising, one of them being Antonenko, for whom he paid an amount of one thousand rubles. After the release of the arrested, the writer brought them to his place, fed them, and gave them money (Кривинская, 1961, p. 65).

The main (in fact the only complete) historical source about Antonenko is the abovepublished text from 1931. The text is accompanied by a photograph on which he appears to be about 50 years old, i.e. it can be assumed, with approximation, that he was born around the year 1880 . Both his birthplace and the date of his death, as well as more details about his life, remain unknown.

\section{Summarising Comments}

The materials presented in this Chapter highlight the starting points of the civic emancipation processes of the Roma in the Austro-Hungarian, Ottoman and Russian Empire. Although relatively small and fragmented, they outline some of the basic directions of their development which are yet to be developed throughout the region of Central, South-Eastern and Eastern Europe in the coming historical eras (including the present day). Moreover, at the same time there have been processes that took place in the same direction among other peoples of these Empires.

The civic emancipation of the Roma de facto replicates in its form, albeit more slowly and to a much lesser extent, the processes of nation-building in the region. These processes, based on Johann Gottfried Herder's concept on modern nationalism, include, as a basic feature, the creation of their own national history and literature, which implies a particular increased interest in the origin, historical past, native language and traditional folklore. These are also present, as we will show below, in some of Roma representatives 
in the Habsburg Empire (or since 1867, the Austro-Hungarian Empire) since the late 18th and especially in the 19th century, and in late Ottoman Empire.

The first Gypsy-Hungarian glossary was made around 1790 in the Calvinist College in Kolozsvár (Cluj-Napoca), with the involvement of Mihály Vistai Farkas, a student of theology of Gypsy origin. In the 19th century, János Ipolysági Balogh (1802-1876), Ferenc Sztojka Nagy-idai (1855-1929), and József Boldizsár (1825-1878), besides their work as native-speakers and language editors of the Dictionary and Grammar of Romani language (Joseph, 1888), produced also the translations in Romani language and original author's literature (Orsós, 2015). In this context, the place of Ferenc Sztojka Nagy-idai and his dictionary of Romani language (Sztojka, 2007), and literary texts (poems, two historical dramas), and especially the already mentioned epic poem, The Wanderings of the Gypsies, should be noted. This poem clearly highlights the interest in the origins and early history of the Gypsies, which is fully in tune with the increased interest in these topics at the dawn of early modern nationalism throughout the region. Sometimes it can be read that "most non intellectual Rom do not seem to care where their ancestors came from" (Stewart, 1997, p. 28). The emergence of the movement for Roma civic emancipation indeed was initiated by a relatively small circle of the Roma elite, as is the case described in the Austro-Hungarian Empire. This is however similar (at least as a model) to the creation of new modern nations in the region, where it was the elites who created national concepts that became subsequently adopted by the masses (Hroch, 2005). During more than three decades of fieldwork in the whole region of Central, South-Eastern and Eastern Europe, however, we have encountered only very few Roma who have no interest in where their ancestors come from. In fact, one can say, the interest in the origin of their community and their history is characteristic for the Roma (intellectuals and non-intellectuals alike) in modern time as a whole (Marushiakova \& Popov 2016a, pp. 16-17).

The main drive in the process for the creation and the publication of the Dictionary and Grammar of Romani language appears to have been one of the members of the Habsburg Dynasty, Archduke Joseph Carl Ludwig von Habsburg (1833-1905), Palatine of Hungary, who at the same time was also one of the founding members of the Gypsy Lore Society, an active member of the Society and its sponsor (Zaloaga, 2014). An interesting aspect of this process of development of Romani language and literature is the clear connection with the development of the Hungarian national idea at that time. As a military musician, János Ipolysági Balogh was an active participant in 1848 in the Hungarian Revolutionary Army and published, in 1850, translations of prayers in the Romani language in a booklet with the highly revealing name Legelső czigány imádságok a melly mind a két magyar hazában levő czigány nemzet számára (Very first Gypsy prayers, which are for both nations in the Hungarian home) (Orsós, 2015). József Boldizsár was also a military musician and participant in the Hungarian Army in 1848, translated into Romani language poems of the Hungarian national hero, the poet Sándor Petőfi, and was buried with military honours as a hero of the Revolution (Petöfiana XXV, 1878:20). In this context, even the creation of the Association of Hungarian Gypsy Musicians and the public support that the organisation received can be linked with the special place 
that Hungarian Gypsy music held as an integral part of the Hungarian national culture (Sárosi, 1971, see Chapter 7).

There is no collision in the phenomenon described, but there is a typical manifestation of the multidimensional identity of Hungarian Gypsies in the era of the formation of civic nations, which on the one hand have an ethnic identity as Gypsies while, at the same time, holding a Hungarian civic national identity. Under the Austro-Hungarian Empire, the acceptance by the Roma of the national identity of the surrounding population reflects their desire for social integration in some of the emerging nations, (in the cases described above, into the Hungarian nation). An expression of this is also evidenced through the participation of Roma in the Czechoslovak Legion during the First World War (Viková, 2018ab), which apparently reflects their desire for integration into the Czech nation. At the same time, similar processes took place among the Gypsies in the Ottoman Empire where some of their representatives became involved in the Bulgarian national movement (see Chapter 2).

Under the Austro-Hungarian Empire, another phenomenon emerged, present in Roma activism throughout the region of Eastern Europe in the following historical eras. It concerns the dialogue (in this case, rather, attempts for a dialogue) of representatives of the Gypsies with the states in which they lived. The desire to engage in this dialogue as representatives of their own communities, expressing their own interests (as they see it) reflects the beliefs of the Roma activists that community problems could be resolved by the authorities (who, for example, should give autonomy to the Gypsies). The Gypsies tried to enter this dialogue from the premise of unequal positions and, therefore, it should be of no surprise that neither the state institutions nor Emperor Franz Josef I himself cared to answer at all.

More specific is the case of Archduke Joseph, who, with his activity and the support he gave to the Gypsy activists, actually helped to initiate the processes of civic emancipation of the Roma in the Austro-Hungarian Empire. This support (de facto financial dependence), however, was limited in scope and did not go beyond its own aims and interests - a problem that continues to have its contemporary dimensions in present-day Roma activism.

The processes of nascent and development of the movement for Roma civic emancipation in the conditions of the Ottoman Empire can only be properly understood and explained if placed in the general context of the era. Also, they used to enjoy relevant civil rights since $15^{\text {th }}$ century, unlike their counterparts in Central and Western Europe who attained such position in society much later.

It is worth mentioning here a specific example of the civil status of the Gypsies in the Ottoman Empire - a case from Bosnia where Selim, the son of Osman, a baker, in 1693 appeared at the court in Sarajevo with the request to be exempt from the payment of the poll-tax (Jizya) 'as an infidel'. In the request, he stated:

I am the son of a Muslim and I am a Muslim. I live in the Muslim quarter, and along with my co-residents, I pay the tithe when I can manage it. Moreover, along with the Muslims I pray 
five times a day and send my children to the religious school to learn the Quran along with the rest of the children. I work on my baking orders, and my lawful wife avoids strangers. (Зиројевић, 1981, р. 240).

With his request, he enclosed his wedding certificate and a circular letter from the Sultan, dealing with the payment of taxes by Muslims. According to the final decision of the court, the claimant was exempt from the payment of poll-tax (Ibid.). This example once again confirms that many of the problems in the Ottoman Empire stem not from existing laws but from their practical application, but one way or another, the presence of civil consciousness among the Gypsies in the Empire (or at least in part of them) is beyond doubt.

There is a specificity of the movement for Roma civic emancipation, which takes different forms and directions, conditioned by the particular situation in different regions of this multinational Empire. In some cases, this movement is closely linked to the national liberation struggles of the Balkan Orthodox peoples (among Roma Christians), and in other cases, it is part of the general development of Ottoman society (among Muslim Gypsies). The reasons for this division are in the overall situation in the Ottoman Empire and the place of the Gypsies in its socio-political structure. The population in the Ottoman Empire was not in equal social positions, as the main division was into two basic categories, distinguished according to the religion - true-believers (Muslim) and infidels (nonMuslims). Gypsies, who were separated by ethnicity in Ottoman law (a relatively rare phenomenon for this Empire), according to their religion (Muslims or Christians) fall into both categories, which in turn predetermines the development of Roma civic emancipation in two main directions and along with this it flows in different forms.

In the Ottoman Empire, as well as in the Austro-Hungarian Empire, the processes of Roma civic emancipation among Christian Gypsies actually repeat (both in basic lines and even in some details) the analogous processes of new nation-building which developed also among other nations with whom they cohabitated the multinational Empires. The specifics of the nation-building process among Roma is firstly in fact, that these processes started to develop later comparing with their neighbouring population; and secondly, that they were relatively more limited in size - as the numbers of Roma visionaries were low (in fact, in the Ottoman Empire, names only of two of them are known - Iliya Naumchev and Emin Resa), as well as the number of constituencies reached by their active propaganda.

In general, in the Ottoman Empire, the civic emancipation of the Roma Christians was closely linked to the development of national movements of other Balkan nations and their national liberation struggles. So, during the First Serbian Uprising (1804-1813), one Gypsy Vojvoda was a member of the Assembly of the Rebel Elders, and on some places, many Gypsies actively participated in the rebel troops, e.g. Janko from Požarevac was a bimbaša (military rank, officer commanding thousand soldiers), the two brothers, Mujo (killed in battle in 1807) and Alija Plavić (beared the title bulyubasha / bulibaša) from Valjevo, and others (Стојанчевић, 1992,pp. 25-26). During the Greek War of Independence 
(1821-29), six Gypsies participated in Alexander Ypsilantis's squad. Judging by their names (Georgi Bukata, Vasily Tsyganin, Vasily Stefan, Ivan Georgiev), most of them originated from Bulgarian lands (Тодоров, 1973, pp. 434-44, 450). Some Gypsies from Sliven (brothers Yordan and Georgi Hadzhikostov, Yordan Ruschev, Dimitar Mandov) joined Bulgarian volunteer army units and auxiliary parts, and they participate in the Russo-Turkish war of 1877-78 for the liberation of Bulgaria (Генов et al., 1968, pp. 9-10). One of these volunteers, Kanyu Dermensky, in 1944, welcomed Soviet troops at Central Square of the city of Sliven (Работническо дело, 1975, р. 3).

However, the full picture was not so unambiguous and relations between Gypsies and other Balkan nations that were Orthodox Christians (Greeks, Serbs, and Bulgarians) were more complicated. Majority of the Gypsies in the Ottoman Empire were Muslim (Marushiakova \& Popov, 2001, p. 46) and, as such, especially in severe times of national struggles, they were perceived as "enemies" by the Christian populations. During the socalled April uprising of Bulgarians in 1876 in the liberated city of Koprivshtitsa rebels slaughtered the entire male Gypsy population - about 40 people (Ibid., p. 58). During the two Balkan Wars, many Gypsies participated in the Serbian army (see Chapter 3), and also in the Bulgarian army (Иванова \& Кръстев, 2014, pp. 16o-230). However, in the course of the war parts of the Bulgarian army performed in the Vasilevo village region (present-day in Republic Northern Macedonia) the mass murder of about 30 Gypsies (Коларов, 2001, pp. 100-103).

The processes of Roma civic emancipation in the Ottoman Empire were not one-sided and straightforward. Many Muslim Gypsies became actively involved in the suppression of the uprisings of the Balkan peoples and in the Russo-Turkish Wars on the side of the Ottoman Empire, i.e. presenting themselves as loyal subjects of the Empire. The Xanthi petition is particularly revealing in this regard. It shows the development of processes dating back centuries, in which parts of the Gypsies in the Empire who sought to escape from the ethnic dimensions of the community, differentiated themselves from other Gypsies, and tried to fit into the general (and ethnically neutral) category of 'Muslims'. On the one hand, these are processes that speak about the birth of civic awareness and the pursuit of better social integration. On the other hand, this leads (due to the overlapping of religious and ethnic identity) to the adoption of a preferred ethnic (in this case Turkish) identity, or even to the creation of a new, non-Roma identity. These are specific processes in which the pursuit of civic emancipation of the community and escape from 'Gypsy stigma' leads to the disappearance of an ethnic community as such and to its transformation into a new community that constructs 'its' own, novel history (e.g. the Balkan Egyptians, Ashkali, Millet, etc.). Such processes in some communities go on for generations and, to this day, they continue to be relevant in the Balkans (Marushiakova \& Popov, 2015, pp. 26-54).

Nevertheless, among Muslim Gypsies in the Ottoman Empire, another civic emancipation tendency emerged. Unlike Roma Christians, who fit into the context of the national revival of their neighbouring Balkan Christian people, they remain in the general discourse of the social development of the Muslim population of the Empire. This 
development led to the establishment of Turkey as a nation-state in early 2oth century (officially in 1923) starting with the so-called Young Turk Revolution (1908) and was characterized by a break with the Ottoman heritage and the replacement of Ottoman identity (closely linked to Muslim religious identity) with Turkish national identity. These common processes in the Empire referred to other Muslim communities that established detached national identities (e.g. the Arabs, Kurds, Albanians, etc.) as well. In this context, the Muslim Roma (or at least some of their representatives) too were trying to find ways for the civic emancipation of their community in the new conditions.

We can see an expression of these aspirations is the emergence of the newspaper Laço. It can be described as the first newspaper written by the Roma without any support from "external" factors (such as religious or state institutions) and their respective attempts to influence Roma communities.

Extremely little is known about the Laço newspaper. In fact, the only sure source about this newspaper is one short article by Henri Bourgeois (1910, pp. 326-329; see more details about this newspaper in Marushiakova \& Popov, 2021). The newspaper Laço ('Good' in Romani language) was published in Edirne (today in Turkey) by Emin Resa (Bourgeois, 1910, p. 326). The two issues of the newspaper about which some information is available are dated 6 and 12 Şubat, 1235; according to the Islamic calendar Rumi used at that time, this means February 19th and February 25th, 1910 (Koloğlu, 1995, pp. 61-62). The newspaper Laço is characterised in the title heading as a "humorous newspaper", that is "serving the interests of the fatherland and the Ottoman nation". In addition, the header of the first issue gives the following two lines "Be blessed a thousand times, $\mathrm{O}$ day that you rise with light and love! There is no longer any hostility, tyranny, or exit", which according to Bourgeois (1910, p. 327) was "obviously an allusion to the recent Turkish freedom", and in fact, it was a reference to the Young Turk revolution which proclaimed new equality of separate nationalities, including Roma, and freedom for free expression of their identity, language and culture and created euphoria in visions for their future.

The newspaper underlines through its title and short dictionary of the Romani language (Ibid.) that national (Ottoman) civic identity does not conflict with the ethnic identity of the community. The newspaper also contains Gypsy national symbols (something which is characteristic of nascent nations), namely graphic illustrations of a blacksmith with a tent in the background (Ibid.). The transition of images of artifacts from everyday life in the field of national symbolism is a common phenomenon among numerous nationalities in many parts of the world. Especially in Edirne, where the newspaper Laço was published, also on all of the poster-invitationg for Kakava holiday (see Chapter 5 for details), the similar drawing appears, with images of smithing tong, anvil, spade and 'cezve' (a Turkish coffee pot) (Şanlıer, 2018); the same objects (as well as other objects used by Blacksmiths or made by them) can be seen depicted on the preserved flags of the Gypsy guilds in the Balkans, the oldest of which is from 1849, from Prizren, in Kosovo (Marushiakova \& Popov, 2016, pp. 80-81).

Unfortunately, nothing more is known about the publisher of the newspaper Laço (and probably its chief editor) Emin Resa; it is only palpable that if he was able to publish a 
newspaper, this means he received a relatively good education. And more importantly, apparently, he was not an extraordinary exception among Muslim Gypsies in its time, because publishing a newspaper implies the existence of possible educated users, i.e. certain strata of Muslim Gypsies in the Ottoman Empire, which possessed at least an initial level of literacy. In the 19th century, after the Russo-Turkish War of 1877-78, as part of the attempt to modernize the Ottoman state, Sultan Abdul Hamid II pursued a policy of pan-Islamism aimed at uniting all Muslims in the empire. In frames of it, a network of primary schools (mekatib-i iptidaiye) and industrial high schools (medaris-i sanai) with Islamic curriculum and Ottoman Turkish as a medium of instruction (Ümit, 2014, p. 33) was developed. One of the targets of this policy were Gypsies, who had to learn their Muslim religion properly. In order not to lose the Muslim population in the neighbouring countries, recently separated from the Empire, the opening of such schools was also carried out in Bulgaria, Serbia, Montenegro, Greece, and Romania (Ulsoy, 2013, pp. 94-98). Gypsies who were recruited in the army were also provided with some kind of basic education.

In the second issue the civic national consciousness among the Roma in the Ottoman Empire is repeatedly declared: "Half of the net proceeds from the sale of this number will be paid for subscription for the national fleet" (Bourgeois, 1910, p. 327). This is not just an empty gesture aimed at ensuring the authorities' favorable treatment of the newspaper and its readersGypsies had their place in the military structure of the early Ottoman Empire, and even in the 16th century, there was a special non-territorial military-administrative unit, the so-called Gypsy sancak with center Kurklareli in Eastern Thrace (Marushiakova \& Popov, 2001, pp. 26-27). In the early 19th century as part of the Ottoman Empire reforms the old Ottoman army was replaced by a regular army and general military conscription. From military service were exempted only the non-Muslims and Gypsies, regardless of their religion, and were had to pay a special army tax (bedel- $i$ askeri) (Ulusoy, 2013, pp. 50).

This was perceived by many Muslim Gypsies as a restriction of their rights and placing them at a disadvantageous position. Evidence of this is numerous petitions from settled Muslim Gypsies that are preserved in Ottoman archives, with pleads to be allowed to serve in the army. One of the most known such petition is addressed to the wāli (governor) of Edirne in 1870. Finally, in 1873 the restriction for serving in the army of Muslim Gypsies was lifted (Ibid., pp. 55-57).

The emergence of the movement for the comprehensive civic emancipation of Roma in the Ottoman Empire is a general historical process. The fact that in the first stages this development took place 'on two tracks' (Christian Roma and Muslim Roma) does not cancel its unity and the commonality of the pursued goals. Moreover, after the disintegration of the Ottoman Empire, already in the conditions of the new nation-states, after the First World War, this internal distinction relatively quickly disappeared. In Turkey remained only Roma Muslims (the Roma Christians in their majority left Turkey in population exchange after the Lausanne agreement in 1923 - see Chapter 4). In the independent Balkan states the significance of the religious difference between Gypsies decreased 
and was replaced with struggles for ethnic unity (cf. more details about this development in Bulgaria in Chapter 2).

The example from the Russian Empire reveals the roots of another important trend in the development of the movement for Roma civic emancipation, which was to unfold in the next historical period. It is about the inclusion of Gypsies in the general sociopolitical struggles, which means that Gypsies' individual representatives start to perceive themselves as an integral part of the general class structure of the society in which they lived and, as a result, they became actively engaged in the fight for the defense of relevant class interests. Viewed in terms of the dichotomy 'community - society', in this case the social (estate-class) dimensions take a dominant position over the community (ethnic) ones. This does not automatically lead to the complete exclusion of the community dimension (i.e. to the pursuit of ethnic assimilation), but to the transformation of it into other social dimensions. This was exactly the dimension in which they searched for ways to solve problems of their own communities. This was a trend that, in many cases (and especially, but not only, in the USSR) could occupy a leading position in the Roma civic emancipation movement throughout the next historical (interwar) period (cf especially the Chapters 2, 5, 12).

This direction in the Roma civic emancipation movement is neither solely nor even determining the overall development of these processes. Nevertheless, it must be taken into account if we are to capture the diversity of this movement and to analyze the main directions and trends in their overall development across the region.

In more general terms, we cannot help but notice that the processes of Roma civic emancipation in the three multinational empires discussed above were the result of efforts of individual representatives of the Roma community, who received no inspiration as ideas, nor financial and other material and technical support from the other national movements. On the contrary, these national movements (Hungarian, Serbian, Bulgarian, etc.) to which the Roma became attached to, tended to incorporate the Roma and to use them in the pursuit of their own goals, rather than to develop the national ideas of the Roma. This, however, did not create any contradictions among them (which is logical in cases of a common enemy). As can be seen later, this situation would change significantly in the coming historical eras in the conditions of the newly created ethnonational states in Central and South-Eastern Europe.

Despite the limited number of Roma visionaries in the Austro-Hungarian and Ottoman Empires, however, they nevertheless succeeded in generating ideas that would continue to develop later on and, overall, remain relevant to this day. These are, for example, an increased interest in the origin and history of their own community, as well as in its language and ethnocultural traditions and folklore; striving for the development of education in the Romani language, for achieving equal citizenship as an ethnic community, for the creation of national autonomy, and even the possibility of creating its own country. A separate issue is that this development remained mainly in the first chronological phase of nation-building, according to the already mentioned concept of Miroslav Hroch (2005), and the second stage (propaganda and the agitation of these national ideas 
among their ethnic community) covered only a limited circle of the community. The case of the Russian Empire, although at first glance does seem to be a direction leading away from the development of these processes, is in fact an integral part of them. This direction of development enriches the common palette and gives new dimensions to the processes of Roma search of their place in modern society.

The palette of cases presented clearly demonstrates that the groundwork for the processes of Roma civic emancipation has already been established before the interwar years.

Elena Marushiakova and Vesselin Popov 